\title{
Mechlorethamine Hydrochloride Gel
}

National Cancer Institute

\section{Source}

National Cancer Institute. Mechlorethamine Hydrochloride Gel. NCI Thesaurus. Code

C119736.

A gel formulation composed of the hydrochloride salt form of mechlorethamine, which is a nitrogen mustard alkylating agent and an analog of sulfur mustard, with antineoplastic and immunosuppressive activities. Upon topical application, mechlorethamine is metabolized to an unstable, highly reactive ethyleniminium intermediate that binds to and alkylates DNA, with a high affinity to the N7 nitrogen of guanine residues. This results in DNA base pair mismatching, DNA interstrand crosslinking, the inhibition of DNA repair and synthesis, cell-cycle arrest, and apoptosis. 